\title{
HUBUNGAN KEPUASAN PELAYANAN MAKANAN DENGAN TINGKAT KECUKUPAN ENERGI DAN PROTEIN PASIEN DI RUMAH SAKIT UNIVERSITAS AIRLANGGA SURABAYA
}

\author{
Amanda Nurqisthy ${ }^{1}$, Merryana Adriani' ${ }^{2}$, Lailatul Muniroh ${ }^{2}$ \\ ${ }^{1}$ Program Studi S1 Ilmu Gizi, Fakultas Kesehatan Masyarakat, Universitas Airlangga, Surabaya \\ ${ }^{2}$ Departemen Gizi Kesehatan, Fakultas Kesehatan Masyarakat, Universitas Airlangga, Surabaya \\ Email: amandanurqisthy@yahoo.com
}

\begin{abstract}
ABSTRAK
Kepuasan pasien merupakan salah satu indikator keberhasilan penyelenggaraan makanan di rumah sakit yang mempengaruhi tingkat kecukupan energi dan protein pasien. Penelitian ini bertujuan untuk menganalisis hubungan kepuasan pelayanan makanan dengan tingkat kecukupan energi dan protein pasien di Rumah Sakit Universitas Airlangga. Penelitian dilakukan dengan desain cross sectional. Penentuan sampel dengan cara purposive sampling, yaitu dengan pembatasan pasien yang mendapatkan diet Tinggi Energi Tinggi Protein dengan besar sampel yaitu 34 pasien. Pengambilan data penelitian dilakukan dengan metode wawancara yang menggunakan panduan kuesioner terkait dengan kepuasan dan pengamatan sisa makanan pasien menggunakan metode taksiran visual Comstock. Data diolah dengan menggunakan uji chi square. Hasil penelitian menunjukkan bahwa sebagian besar tingkat kecukupan energi dan protein pasien $(73,5 \%$ dan $70,6 \%)$ dalam kategori adekuat dan sebagian besar pasien menyatakan puas (76,5\%) terhadap pelayanan makanan rumah sakit. Ada hubungan antara kepuasan pelayanan makanan rumah sakit dengan tingkat kecukupan energi dan protein pasien $(p=0,017$ dan $p=0,031)$. Pasien yang puas terhadap pelayanan makanan rumah sakit memiliki tingkat kecukupan energi dan protein yang baik. Perlu dilakukan perbaikan sistem penyelenggaraan makanan rumah sakit terutama pada ketepatan waktu pemberian makan dan cita rasa makanan mengingat pada indikator tersebut masih ditemukan ketidakpuasan pasien.
\end{abstract}

Kata kunci: kepuasan pelayanan makanan, pasien, tingkat kecukupan energi dan protein

\section{ABSTRACT}

Patient's satisfaction is one of success indicator of hospital food service, which affect the level of energy and protein sufficiency of patients. The aim of this study was to analyze the relationship between food service satisfaction and energy and protein sufficiency level of patients in Universitas Airlangga Hospital. Thirty-four samples who receive High Energy and Protein diet were chosen using purposive sampling. Patient satisfaction data was collected through interview using a questionnaire and food waste was analyze through observation by Comstock method. Data was processed using chi square test. The result showed that level of energy and protein sufficiency of most patients are adequate (73.5\% and 70.6\%) and most patient are satisfied with the hospital food service (76.5\%). There was a relationship between satisfaction of food service with the level of energy and protein sufficiency of patients $(p=0.017$ and $p=0.031)$. Patients who were satisfied with the food services of hospital has a sufficient intake of energy and protein. It is needed to restore system of food operation in hospital, especially on the punctuality of food distribution and flavor of food, considering that those indicator, were source of dissatisfaction.

Keywords: food service satisfaction, patients, the level of energy and protein sufficiency

\section{PENDAHULUAN}

Dukungan gizi merupakan bagian dari terapi yang berperan penting dalam kesembuhan pasien. Dukungan gizi yang optimal akan meningkatkan daya tahan tubuh pasien sehingga juga akan meningkatkan kemampuan tubuh untuk melawan penyakit (Lipoeto, 2006).

Tingkat kecukupan energi dan protein menjadi hal penting untuk diperhatikan dalam upaya untuk mempercepat penyembuhan pasien. 
Makanan yang dikonsumsi oleh pasien harus dapat memenuhi kebutuhan zat gizi dari segi kuantitas dan kualitasnya. Konsumsi makanan yang lebih ditekankan adalah kebutuhan energi dan protein, karena jika kebutuhan tersebut telah terpenuhi maka kebutuhan zat gizi lainnya juga akan terpenuhi, sehingga tidak terlalu sulit untuk memenuhinya (Mutmainnah, 2008).

Penelitian yang dilakukan di RSUP H. Adam Malik Medan pada pasien rawat inap pada bulan Desember 2012, rata-rata hanya sebesar $61,4 \%$ pasien rawat yang menghabiskan makanan rumah sakit. Selain itu, hasil penelitian Mutmainnah (2008) menunjukkan bahwa tingkat konsumsi energi dan protein terhadap kebutuhan sebagian besar pasien masih tergolong defisit. Hanya 18,3\% pasien yang memiliki tingkat konsumsi energi dan protein normal. Kondisi tersebut menunjukkan bahwa secara umum konsumsi makanan pasien belum dapat mencukupi kebutuhan energi dan proteinnya. Lebih lanjut, penelitian yang dilakukan oleh Weta (2009) di RSUP Sanglah Denpasar menunjukkan bahwa rata-rata tingkat konsumsi energi dan protein pasien masih berada di bawah kebutuhan yaitu sebesar 78,1\% untuk tingkat konsumsi energi dan 78,3\% untuk tingkat konsumsi protein.

Tingkat kecukupan energi dan protein pasien dapat dipengaruhi oleh penilaian kualitas makanan yang merupakan bentuk dari kepuasan pasien terhadap makanan yang disajikan di rumah sakit. oleh karena itu, dapat diartikan bahwa kepuasan pelayanan makanan pada pasien akan mempengaruhi tingkat kecukupan energi dan proteinnya. Selain itu, kepuasan pelayanan makan pasien merupakan salah satu indikator keberhasilan penyelenggaraan makanan di rumah sakit.

Kepuasan yang diperoleh pasien dalam penyelenggaraan makanan rumah sakit dapat diidentifikasi dari ekspektasi produk dan persepsi pasien terhadap kualitas pelayanan (Hartwell, 2006). Hasil penelitian Oktaria (2014) mengatakan bahwa pasien yang mendapatkan layanan gizi di Rumah Sakit Bhayangkara menunjukkan ketidakpuasan, terlihat dari banyaknya sisa makanan pasien yang melebihi $25 \%$, sedangkan Standar Pelayanan Minimal (SPM) rumah sakit dalam Kemenkes RI (2008) yaitu $\leq 20 \%$. Selain itu, penelitian Schueren, et al. (2012) di 150 RS menunjukkan bahwa hanya sebanyak $27 \%$ pasien yang menghabiskan makanan yang disajikan, sebesar $44 \%$ pasien menghabiskan makanan lebih dari separuh, dan $29 \%$ pasien yang menghabiskan makanan kurang dari separuh. Hal tersebut pada akhirnya menyebabkan tingginya angka sisa makanan yang berujung pada ketidakadekuatan konsumsi energi dan protein pasien yang berkaitan pula dengan tingkat kecukupan energi dan protein.

Berdasarkan hasil studi pendahuluan dengan Ahli Gizi di Rumah Sakit Universitas Airlangga, dijelaskan bahwa ahli gizi RSUA masih mendapatkan komplain dari pasien terkait dengan makanan yang disajikan, salah satunya yaitu mengenai cita rasa dari makanan. Selain itu, ahli gizi tersebut juga menyatakan bahwa sisa makanan di rumah sakit masih cukup banyak. Sebagian besar pasien menyisakan sayur dan nasi pada menu yang disajikan. Hal tersebut akan mempengaruhi adanya sisa makanan rumah sakit. Sisa makanan rumah sakit akan mempengaruhi tingkat kecukupan energi dan protein seseorang sehingga berdampak terhadap status gizi.

Sesuai dengan Kemenkes RI (2013), faktorfaktor yang dapat mempengaruhi kepuasan pasien adalah ketepatan waktu distribusi makanan, variasi menu makanan, cita rasa makanan, kebersihan alat, serta penampilan petugas. Bentuk kepuasan pasien terhadap makanan yang disediakan rumah sakit yaitu dapat dilihat dari tingkat kecukupan energi dan protein pasien selama dirawat.

Sebelumnya, di Rumah Sakit Universitas Airlangga belum ada penelitian terkait dengan kepuasan pelayanan makanan rumah sakit, melainkan hanya sebatas wawancara terkait dengan cita rasa makanan yang disajikan di rumah sakit. Penelitian ini bertujuan untuk menganalisis hubungan kepuasan pelayanan makanan dengan tingkat kecukupan energi dan protein pasien di Rumah Sakit Universitas Airlangga Surabaya.

\section{METODE}

Penelitian ini merupakan penelitian observasional analitik dengan pendekatan cross sectional. Populasi penelitian ini adalah seluruh 
pasien rawat inap di Rumah Sakit Universitas Airlangga Surabaya yaitu berjumlah 60 pasien dengan besar sampel 34 pasien. Sampel diambil dengan menggunakan metode purposive sampling dengan kriteria pasien yaitu mendapatkan diet Tinggi Energi Tinggi Protein (TETP) makanan biasa tanpa mempertimbangkan jenis penyakit pasien, berusia 17-65 tahun, tidak mendapatkan makanan dari luar rumah sakit. Penelitian dilaksanakan pada bulan Februari-Juni 2016. Penelitian dilakukan di ruang rawat inap Rumah Sakit Universitas Airlangga Surabaya.

Penelitian dilakukan dengan metode wawancara menggunakan panduan kuesioner kepuasan pelayanan makanan yang meliputi indikator ketepatan waktu distribusi makanan, variasi menu, cita rasa makanan, kebersihan alat, dan penampilan petugas. Selanjutnya dilakukan scoring menggunakan skala Likert dengan 4 kategori tingkat kepuasan yaitu sangat tidak puas, tidak puas, puas, dan sangat puas yang masingmasing diberi skor 1-4, kemudian dikompositkan dan dikatakan puas apabila skor $\geq 62,5 \%$ dan tidak puas apabila skor $<62,5 \%$ (Sugiyono, 2009).

Diet Tinggi Energi dan Tinggi Protein (TETP) dibagi berdasarkan kelas perawatan pasien. Kebutuhan energi pasien Kelas 1 sebesar 1900 kalori dan kebutuhan protein 95 gram, serta kelas 2 sebesar 1800 kalori dan kebutuhan protein 68 gram. Untuk menghitung sisa makanan pasien menggunakan metode Comstock (Williams and Walton, 2010). Asupan makan pasien pada saat dirawat dihitung dengan cara menghitung konsumsi makan pasien dalam setiap menunya yang satu hari terdiri dari 3 kali menu utama dan 2 kali selingan, selanjutnya dikurangi sisa makanan pasien. Tingkat kecukupan energi dan protein pasien dilakukan dengan cara membandingkan asupan makan pasien dengan standar kebutuhan energi dan protein yang ditetapkan oleh rumah sakit. Hasil tersebut kemudian dikategorikan menurut Gibson (2005) yaitu adekuat $(\geq 77 \%$ Standar Pemberian Makanan Rumah Sakit) dan inadekuat $(<77 \%$ Standar Pemberian Makanan Rumah Sakit).

Instrumen pengumpulan data yang digunakan yaitu kuesioner kepuasan pelayanan makanan dan form sisa makanan. Analisis hubungan kepuasan pelayanan makan rumah sakit dan tingkat kecukupan energi dan protein dengan status gizi pasien diolah dengan uji chi square. Penelitian ini telah mendapatkan persetujuan dari Komisi Etik Penelitian Kesehatan No: 170-KEPK Fakultas Kesehatan Masyarakat Universitas Airlangga Surabaya.

\section{HASIL DAN PEMBAHASAN}

\section{Karakteristik Responden}

Karakteristik pasien yang diteliti meliputi umur, jenis kelamin, serta pekerjaan pasien. Berikut adalah tabel distribusi karakteristik pasien di RSUA Tahun 2016.

Tabel 1 menunjukkan bahwa sebesar 29,4\% pasien berada pada kelompok umur remaja akhir dan lansia akhir. Menurut Soetjiningsih (2007), usia remaja merupakan periode rawan gizi. Hal ini disebabkan karena pada usia remaja memerlukan zat gizi yang lebih tinggi, terutama pada kebutuhan energi dan protein sebagaimana zat tersebut sangat berperan penting dalam masa pertumbuhan. Di samping usia remaja, usia lansia juga perlu diperhatikan kebutuhan energi dan proteinnya. Pada umumnya, usia lansia mengalami

Tabel 1. Distribusi Karakteristik Pasien di RSUA Tahun 2016

\begin{tabular}{lcc}
\hline \multicolumn{1}{c}{ Karakteristik Pasien } & $\begin{array}{c}\text { Jumlah (n) } \\
\mathbf{n}=\mathbf{3 4}\end{array}$ & $\begin{array}{c}\text { Persen } \\
\text { (\%) }\end{array}$ \\
\hline Kelompok Umur & & \\
Remaja Akhir & 10 & 29,4 \\
(17-25 tahun) & & \\
Dewasa Awal & 5 & 14,7 \\
(26-35 tahun) & & \\
Dewasa Akhir & 3 & 8,8 \\
(26-45 tahun) & & \\
Lansia Awal & 6 & 17,6 \\
(46-55 tahun) & & \\
Lansia Akhir & 10 & 29,4 \\
(56-65 tahun) & & \\
Jenis Kelamin & & \\
Laki-laki & 17 & 50,0 \\
Perempuan & 17 & 50,0 \\
Pekerjaan & & \\
Tidak Bekerja & 15 & 44,1 \\
Pelajar & 3 & 8,8 \\
Swasta & 15 & 44,1 \\
Wiraswasta & 1 & 2,9 \\
\hline
\end{tabular}


penurunan fungsi fisiologis pada rongga mulut, yang tentunya akan berdampak terhadap proses pengunyahan makanan, sehingga hal tersebut akan mempengaruhi nafsu makan. Lansia akan cenderung mengalami penurunan nafsu makan sehingga status gizinya berada dalam kategori di bawah normal. Terpenuhinya kebutuhan energi dan protein lansia sangat penting untuk mempertahankan fungsi tubuh, aktivitas otot dan pertumbuhan serta membatasi kerusakan yang menyebabkan penuaan dan penyakit (Barasi, 2007).

Karakteristik pasien berdasarkan jenis kelamin pada Tabel 1 menunjukkan bahwa persentase pasien laki-laki sama dengan persentase pasien perempuan yaitu sebesar 50,0\%. Jenis kelamin menentukan besar kecilnya asupan gizi yang dikonsumsi. Energi minimal yang diperlukan perempuan sepuluh persen lebih rendah daripada yang diperlukan laki-laki sehingga kebutuhan zat gizinya akan berbeda (Kartasapoetra dan Marsetyo, 2008). Namun, jumlah kebutuhan energi dan protein di RSUA tidak dibedakan berdasarkan jenis kelamin, melainkan telah disediakan standar kecukupan energi dan protein bagi pasien berdasarkan kelas perawatan.

Distribusi karakteristik pekerjaan pasien menunjukkan bahwa sebesar $44,1 \%$ pasien dengan status tidak bekerja dan swasta. Pekerjaan merupakan aktivitas jasa seseorang untuk mendapatkan imbalan berupa materi dan non materi. Pekerjaan dapat menjadi faktor risiko kesehatan seseorang dan berdampak pada sistem imunitas tubuh. Pekerjaan ada hubungannya dengan penghasilan seseorang untuk berperilaku dalam menentukan pelayanan yang diinginkan.

\section{Kepuasan Pelayanan Makanan}

Berikut adalah tabel distribusi kepuasan pelayanan makanan pasien. Tabel 2 menunjukkan bahwa sebagian besar pasien menyatakan puas terhadap ketepatan waktu pemberian makan $(67,6 \%)$, variasi menu $(100,0 \%)$, cita rasa makanan $(70,6 \%)$, kebersihan alat $(100 \%)$, serta penampilan petugas $(100 \%)$. Pada indikator variasi menu, kebersihan alat, dan penampilan petugas, seluruh pasien menyatakan puas pada ketiga indikator tersebut. Sesuai dengan penelitian Isnaeni (2015)
Tabel 2. Tabel Distribusi Kepuasan Pelayanan Makanan Pasien

\begin{tabular}{lcrrr}
\hline \multirow{2}{*}{ Indikator Penilaian } & \multicolumn{4}{c}{ Kepuasan } \\
\cline { 2 - 5 } & \multicolumn{1}{c}{ Puas } & \multicolumn{4}{c}{ Tidak Puas } \\
\cline { 2 - 5 } Ketepatan Waktu & 23 & 67,6 & 11 & \multicolumn{1}{c}{ n } \\
Pemberian Makan & & 100,0 & 0 & 0,0 \\
Variasi Menu & 34 & 70,6 & 10 & 29,4 \\
Cita Rasa Makanan & 24 & 0 & 0,0 \\
Kebersihan Alat & 34 & 100,0 & 0 & 0,0 \\
Penampilan Petugas & 34 & 100,0 & 0 & 0,0 \\
\hline
\end{tabular}

bahwa pada ketiga indikator tersebut, sebagian besar pasien merasa puas.

Menurut Depkes RI (2007), menu yang bervariasi dapat merangsang selera makan sehingga makanan yang disajikan akan dihabiskan oleh pasien. Terkait dengan kebersihan alat, Kemenkes RI (2013) menyatakan bahwa peralatan harus dijaga agar selalu tetap bersih. Peralatan makan pasien di RSUA telah terjaga kebersihannya, hal tersebut telah dibuktikan bahwa penilaian seluruh pasien di RSUA yang menilai puas dengan kebersihan peralatan. Selain itu, penampilan petugas juga berpengaruh pada kepuasan pasien. Sesuai dengan pernyataan Nuryati (2008) yang menyatakan bahwa penampilan petugas merupakan hal yang penting karena akan mempengaruhi pasien dalam menikmati makanan dan akhirnya dapat menimbulkan rasa puas.

Pada hasil tersebut, masih didapatkan angka ketidakpuasan pasien yaitu pada indikator ketepatan waktu pemberian makan $(32,4 \%)$ dan cita rasa makanan $(29,4 \%)$. Hal tersebut sesuai dengan penelitian Ernalia (2014) bahwa masih terdapat pasien yang menyatakan tidak puas terhadap ketepatan waktu distribusi makanan serta cita rasa makanan, sehingga dalam penelitian tersebut mengatakan bahwa ada hubungan yang bermakna antara ketepatan waktu distribusi makanan dan cita rasa makanan dengan kepuasan pasien.

Pada penelitian yang dilakukan, adanya nilai ketidakpuasan dari pasien terkait dengan ketepatan waktu distribusi makanan dikarenakan beberapa pasien mengeluh bahwa jam pemberian makan pagi yang sering terlambat sehingga pasien mengeluh merasa lapar ketika makanan datang terlambat. 
Selain itu, jam pemberian makan malam yang terlalu cepat yaitu pukul 16.00 WIB, sedangkan menurut sebagian pasien pada jam tersebut belum masuk jam makan malam dan pasien merasa bahwa jarak waktu antara makan siang dan makan malam terlalu pendek, sehingga pasien masih merasa kenyang pada jam tersebut.

Pada indikator cita rasa makanan juga ditemukan angka ketidakpuasan pasien terhadap makanan yang disajikan. Hal tersebut kemungkinan dapat disebabkan karena pasien mengalami perubahan/gangguan indera perasa yang diakibatkan karena sakit yang diderita pasien, mengingat pasien dalam kondisi penyakit yang berbeda-beda, namun dalam penelitian ini tidak mengamati jenis penyakit yang diderita oleh pasien, melainkan hanya mempertimbangkan jenis diet pasien. Penilaian cita rasa makanan dalam kuesioner meliputi warna, rasa, aroma, dan tekstur makanan. Pada saat penelitian berlangsung, beberapa pasien juga mengeluh bahwa nasi yang disajikan masih kurang matang sehingga pada indikator cita rasa makanan masih didapatkan angka ketidakpuasan, meskipun sebagian besar pasien mengatakan puas.

Berikut adalah Tabel distribusi kepuasan pelayanan makanan pasien akan disajikan pada Tabel 3. Tabel 3 menunjukkan bahwa sebagian besar pasien menyatakan puas (76,5\%), sedangkan sisanya menyatakan tidak puas $(23,5 \%)$. Hal tersebut dapat diartikan bahwa pelayanan makanan rumah sakit yang telah diterapkan di RSUA sudah cukup baik.

Sejalan dengan penelitian Cahyawari (2013) bahwa sebagian pasien merasa puas dengan pelayanan makanan yang ada di rumah sakit, walaupun terdapat beberapa pasien yang tidak puas terhadap pelayanan makanan selama dirawat di rumah sakit. Demikian pula penelitian Paruntu (2013) yang menyatakan bahwa sebagian pasien

Tabel 3. Distribusi Kepuasan Pelayanan Makanan Pasien di RSUA Tahun 2016

\begin{tabular}{lrc}
\hline \multicolumn{1}{c}{$\begin{array}{c}\text { Kepuasan Pelayanan } \\
\text { Makanan }\end{array}$} & n & \% \\
\hline Puas & 26 & 76,5 \\
Tidak Puas & 8 & 23,5 \\
\hline Jumlah & 34 & 100,0 \\
\hline
\end{tabular}

merasa puas terhadap pelayanan makan yang disajikan di rumah sakit.

Pada penelitian yang dilakukan, ditemukan ketidakpuasan oleh pasien dikarenakan masih adanya beberapa faktor dari kepuasan pelayanan makanan rumah sakit yang dirasa kurang memuaskan bagi konsumen yaitu ketepatan waktu pemberian makan serta cita rasa makanan. Namun demikian, pendapat kepuasan dinilai secara subjektif, sehingga setiap pasien akan menilai sesuai dengan selera masing-masing.

\section{Tingkat Kecukupan Energi dan Protein Pasien}

Berikut adalah tabel distribusi tingkat kecukupan energi dan protein pasien di RSUA Tahun 2016. Tabel 4 menunjukkan bahwa sebagian besar rata-rata tingkat kecukupan energi dan protein pasien selama 3 hari dengan kategori adekuat masing-masing sebesar $73,5 \%$ dan $70,6 \%$, sedangkan kategori inadekuat sebesar 26,5\% dan $29,4 \%$. Hal tersebut dapat diartikan bahwa kebutuhan energi dan protein sebagian besar pasien selama dirawat di rumah sakit telah terpenuhi.

RSUA belum memiliki standar total energi dan zat gizi dalam setiap menu, melainkan hanya menuliskan jenis diet beserta jumlah kalorinya tersebut di buku rekaman pasien, namun setelah dilakukan perhitungan dari total menu sehari, menu tersebut dapat memenuhi kebutuhan energi pasien, diantaranya Kelas 1 sebesar 1900 kalori dan kebutuhan protein 95 gram, serta kelas 2 sebesar 1800 kalori dan kebutuhan protein 68 gram.

Sejalan dengan penelitian Semedi (2013) yang menyatakan bahwa tingkat kecukupan energi dan protein pasien pada saat dirawat di rumah sakit sebagian besar telah terpenuhi. Hal tersebut tidak selaras dengan penelitian yang telah dilakukan oleh Schueren, et al. (2012) bahwa di 150 RS menunjukkan sisa makanan yang tinggi sehingga berujung pada ketidakadekuatan konsumsi energi

Tabel 4. Distribusi Tingkat Kecukupan Energi dan Protein Pasien di RSUA Tahun 2016

\begin{tabular}{lrccc}
\hline \multirow{2}{*}{ Kategori } & \multicolumn{2}{c}{ Energi } & \multicolumn{2}{c}{ Protein } \\
\cline { 2 - 5 } & n & \% & n & \% \\
\hline Adekuat & 25 & 73,5 & 24 & 70,6 \\
Inadekuat & 9 & 26,5 & 10 & 29,4 \\
\hline Jumlah & 34 & 100,0 & 34 & 100,0 \\
\hline
\end{tabular}


dan protein pasien, sehingga tingkat kecukupan energi dan protein pasien sebagian besar belum terpenuhi.

Terdapat banyak faktor yang dapat mempengaruhi tingkat kecukupan energi dan protein pada pasien, diantaranya yaitu pasien mengalami penurunan nafsu makan sehingga akan berdampak pada kecukupan energi dan protein pasien, sebagaimana pada saat penelitian berlangsung beberapa pasien tidak menghabiskan makanan yang disajikan terutama pada lauk hewani sehingga dengan begitu terdapat beberapa pasien yang tingkat kecukupan proteinnya berada dalam kategori inadekuat.

Pada penelitian yang dilakukan, meski terdapat tingkat kecukupan energi dan protein pasien dalam kategori inadekuat, persentase tingkat kecukupan energi dan protein yang berada dalam kategori adekuat lebih besar. Hal tersebut menunjukkan bahwa sebagian besar pasien dapat menerima makanan yang disediakan oleh rumah sakit.

Pasien yang tidak menghabiskan makanan yang diberikan rumah sakit akan berisiko menderita malnutrisi dikarenakan tidak terpenuhinya kecukupan energi dan protein pasien. Asupan makan yang rendah pada pasien merupakan salah satu penyebab terjadinya gizi kurang (Sjamsuhidajat, 2010).

Secara langsung, keadaan gizi kurang disebabkan oleh asupan yang rendah dari kebutuhan seharusnya. Akhirnya, untuk memenuhi kebutuhan digunakan energi dalam tubuh dari cadangan lemak, pemecahan jaringan akan diikuti oleh penurunan berat badan sebanyak lemak yang digunakan. Apabila keadaan ini berlangsung lama, maka seseorang akan menjadi kurus dan berakibat terjadinya energi kurang dan kronis. Beberapa faktor yang secara langsung maupun tidak langsung menyebabkan asupan makan yang kurang selama rawat inap antara lain pasien terlalu lama dipuasakan, tidak diperhitungkan penambahan zat gizi, obat-obatan yang diberikan, gejala gangguan gastrointestinal, serta penyakit yang menyertai (Suharyati, 2006).

\section{Hubungan Kepuasan Pelayanan Makanan Rumah Sakit dengan Tingkat Kecukupan Energi dan Protein}

Hubungan kepuasan pelayanan makanan rumah sakit dengan tingkat kecukupan energi dan protein pasien di RSUA Tahun 2016 disajikan pada Tabel 5. Tabel 5 menunjukkan bahwa sebagian besar pasien $(64,7 \%$ dan $61,8 \%)$ yang menyatakan puas memiliki tingkat kecukupan energi dan protein yang adekuat. Berdasarkan uji statistik dengan menggunakan chi square, didapatkan hasil pada hubungan kepuasan pelayanan makanan dengan tingkat kecukupan energi $(p=0,017)$ dan hubungan kepuasan pelayanan makanan dengan tingkat kecukupan energi $(p=0,031)$. Hal tersebut menunjukkan bahwa ada hubungan antara kepuasan pelayanan makanan rumah sakit dengan tingkat kecukupan energi dan protein pasien. Hal tersebut dapat diartikan bahwa apabila pasien puas terhadap pelayanan makanan rumah sakit, maka kebutuhan energi dan protein pasien cenderung akan terpenuhi.

Sesuai dengan penelitian yang dilakukan oleh Cahyawari (2013) bahwa pada subjek dengan sisa makanan sedikit merupakan subjek yang menilai kepuasan lebih besar dibandingkan dengan yang menilai tidak puas. Selain itu, penelitian Semedi (2013) yang juga menyatakan bahwa terdapat hubungan positif dan bermakna antara kepuasan pelayanan makanan dengan asupan energi dan protein.

Selain itu, beberapa teori juga menyatakan bahwa kepuasan pelayanan makanan RS sangat berpengaruh terhadap asupan makanan pasien.

Tabel 5. Hubungan Kepuasan Pelayanan Makanan dengan Tingkat Kecukupan Energi dan Protein Pasien di RSUA Tahun 2016

\begin{tabular}{|c|c|c|c|c|c|c|c|c|c|c|}
\hline \multirow{4}{*}{ Kepuasan } & \multicolumn{4}{|c|}{ Tingkat Kecukupan } & \multirow{4}{*}{ P-value } & \multicolumn{4}{|c|}{ Tingkat Kecukupan } & \multirow{4}{*}{ P-value } \\
\hline & \multicolumn{4}{|c|}{ Energi } & & \multicolumn{4}{|c|}{ Protein } & \\
\hline & \multicolumn{2}{|c|}{ Adekuat } & \multicolumn{2}{|c|}{ Inadekuat } & & \multicolumn{2}{|c|}{ Adekuat } & \multicolumn{2}{|c|}{ Inadekuat } & \\
\hline & $\mathbf{n}$ & $\%$ & $\mathbf{n}$ & $\%$ & & $\mathbf{n}$ & $\%$ & $\mathbf{n}$ & $\%$ & \\
\hline Puas & 22 & 64,7 & 4 & 11,8 & \multirow{2}{*}{0,017} & 21 & 61,8 & 5 & 14,7 & \multirow{2}{*}{0,031} \\
\hline Tidak Puas & 3 & 8,8 & 5 & 14,7 & & 3 & 8,8 & 5 & 14,7 & \\
\hline
\end{tabular}


Pasien yang merasa puas dengan pelayanan makanan RS, mempunyai dampak terhadap asupan makan yang tinggi dan sisa makan yang sedikit.

Kepuasan dirasakan oleh seseorang yang telah mengalami suatu hasil yang sesuai dengan harapannya. Kepuasan pasien terhadap penyelenggaraan makanan di rumah sakit dapat diidentifikasi dari ekspektasi produk dan persepsi pasien terhadap kualitas pelayanan (Hartwell, 2006). Pasien yang mau menghabiskan makanan yang disajikan di rumah sakit akan dapat mempercepat proses penyembuhan. Selain itu, pasien yang merasa puas terhadap pelayanan makanan rumah sakit, tingkat kecukupan energi dan protein pasien selama dirawat di rumah sakit akan cenderung adekuat.

\section{KESIMPULAN DAN SARAN}

Pasien yang merasa puas dengan makanan yang disajikan memiliki tingkat kecukupan energi dan protein yang adekuat selama dirawat di rumah sakit. Terkait dengan hal tersebut, perlu dilakukan perbaikan sistem pada penyelenggaraan makanan rumah sakit terutama pada indikator ketepatan waktu pemberian makanan dan cita rasa makanan, mengingat pada hasil penelitian ditemukan beberapa pasien yang menyatakan tidak puas terhadap indikator tersebut, walaupun ratarata nilai kepuasan pasien secara keseluruhan dari kelima indikator menyatakan puas.

\section{DAFTAR PUSTAKA}

Cahyawari, M. (2013). Hubungan antara Kualitas Pelayanan Makanan dan Tingkat Kepuasan dengan Sisa Makanan Pasien Diabetes Mellitus Tipe II Rawat Inap di RS PKU Muhammadiyah Surakarta. Jurnal Kesehatan, 52(1), 1-13. Diakses dari http://eprints.ums.ac.id/27080/9/ NASKAH_PUBLIKASI.pdf.

Depkes RI. (2007). Pedoman Pelayanan Gizi Rumah Sakit. Jakarta: Direktorat Gizi Masyarakat.

Ernalia, Y. (2014). Faktor-faktor yang Berhubungan dengan Kepuasan Pasien di Ruang Penyakit Dalam dan Ruang Bersalin terhadap Pelayanan Makanan Pasien di RSUD Mandau Duri Tahun 2014. Jurnal Gizi STIKes Tuanku Tambusai Riau, 34(3), 36-37. Diakses dari http://lppm. tuankutambusai.ac.id/2015/09/23/faktor-faktor- yang-berhubungan-dengan-kepuasan-pasiendi-ruang-penyakit-dalam-dan-ruang-bersalinterhadap-pelayanan-makanan-pasien-di-rsudmandau-duri-tahun-2014/

Hartwell, H. (2006). Food Service in Hospital: Development of a Theoretical Modedl Foe Patient Experiemce and Satisfaction Using on Hospital in the UK National Health Service as a case Study. Journal of Food Service, 17(1), 226-238. Diakses dari http://onlinelibrary.wiley. com/doi/10.1111/j.1745-4506.2006.00040.x/ abstract.

Isnaeni, P. (2015). Hubungan Mutu Pelayanan Gizi dengan Kepuasan Pasien Rawat Inap di rumah Sakit Umum Aminah Blitar. Journal of Hospital Management and Medicoeticolegal, 3(2), 1-18. Diakses dari http://thesis.umy.ac.id/datapublik/ t52993.pdf.

Kartasapoetra, G dan Marsetyo, H. (2008). Ilmu Gizi: Korelasi Gizi, Kesehatan dan Produktivitas Kerja. Jakarta: Rineka Cipta.

Kemenkes RI. (2008). Peraturan Menteri Kesehatan Republik Indonesia tentang Standar Pelayanan Minimal Rumah Sakit Nomor 129/ Menkes/SK/II/2008. Jakarta: Kemenkes RI. Diakses dari http://www.pelkesi.or.id/index. php?option $=$ com_jotloader\&section $=$ files\&tas $\mathrm{k}=$ download\&cid=16_7c615c64254e8d50eb2 6446be44271 fa\&Itemid $=123$.

Kemenkes RI. (2013). Pedoman Pelayanan Gizi Rumah Sakit. Jakarta: Kemenkes RI. Diakses dari http://gizi.depkes.go.id/download/ Pedoman\%20Gizi/COVER\%PGRS PGRS\%20 Final.pdf

Lipoeto, N. (2006). Malnutrisi dan Asupan Kalori Pasien Rawat Inap di Rumah Sakit. Majalah Kedokteran Indonesia,56(11), 1-14. Diakses dari http://repository.unand.ac.id/26/1/ konsumsi kalori-bb imt.pdf

Mutmainnah. (2008). Daya Terima Makanan dan Tingkat Konsumsi Energi-Protein Pasien Rawat Inap Penderita Penyakit Dalam di Rumah Sakit Dr. H. Marzoeki Mahdi. Jurnal Gizi dan Pangan. 3(1), 22-39. Diakses dari http://repository. ipb.ac.id/bitstream/handle/123456789/2465/ A08mut.pdf;jessionid=D70F5E1B8F3AB860 3D4C1845E5DAF1F9? sequence $=5$.

Nuryati, P. (2008). Hubungan antara Waktu Penyajian, Penampilan, dan Rasa Makanan dengan Sisa Makanan pada Pasien Rawat Inap Dewasa di Rumah Sakit Bhakti Wira Tamtama Semarang. Jurnal Gizi Unimus, 36(2), 13-26. 
Universitas Muhammadiyah. Diakses dari http://digilib.unimus.ac.id/gdl.php?mod=bro wse\&op=read\&id=jtptunimus-gdl-s1-2008pujinuryati-500.

Oktaria. (2014). Hubungan Kepuasan Pelayanan Gizi dengan Sisa Makanan Pasien di Rumah Sakit Bhayangkara Kediri. (Skripsi yang tidak terpublikasi). Universitas Brawijaya, Malang.

Paruntu. (2013). Status Gizi dan Penyelenggaraan Makanan Diet Pasien Rawat Inap di BLU Prof. Dr. R.D. Kandou Manado. Jurnal Gizido, 5(2), 11-19 .Diakses dari http://ejurnal. poltekkesmanado.ac.id/index.php/gizido/ article/download/289/304

Retnani, I. (2014). Hubungan antara Umur dan Paritas Ibu Bersalin dengan Kejadian Pre Eklampsia. Jurnal Akbid Griyahusada, 2(1), 44-50. Diakses dari http://jurnal. akbid-griyahusada.ac.id/iles/vol2no1/ Penelitian2.8.pdf
SchuerenMA, Roosemalen MM, Weijs PJ, Langius JA. (2012). High Waste Contributes to Low Food Intake in Hospitalized Patients. Nutritional in Clinical Practice, XX(X), 1-7. Diakses dari http://www.ncbi.nlm.nih.gov/ pubmed/22378801

Semedi, P. (2013). Hubungan Kepuasan Pelayanan Makanan Rumah Sakit dan Asupan Makanan dengan Perubahan Status Gizi Pasien (Studi di RSUD Sunan Kalijaga Kabupaten Demak). Jurnal Gizi Indonesia, 2(1), 32-41. Diakses dari http://ejournal.undip.ac.id/index.php/jgi/article/ view/6343/5313.

Weta, I. (2009). Kecukupan Zat Gizi dan Perubahan Status Gizi Pasien selama Dirawat di Rumah Sakit Umum Pusat Sanglah Denpasar. Jurnal Gizi Indonesia, 32(2), 139-149. Diakses dari http://ejournal.persagi.org/go/index.php/Gizi Indon/article/download/78/75. 